\title{
The Effect of One-way and Two-way Tasks on Iranian EFL Learners' Lexical Learning
}

\author{
Saeedeh Shadabi \\ Department of English, Yazd Branch, Islamic Azad University, Yazd, Iran \\ Mohammad Golshan \\ Department of English, Maybod Branch, Islamic Azad University, Maybod, Yazd, Iran \\ Sima Sayadian \\ Department of English, Maybod Branch, Islamic Azad University, Maybod, Yazd, Iran
}

\begin{abstract}
This study investigated the effect of one-way and two-way tasks on lexical learning of Iranian preintermediate EFL learners. Participants included 40 male and female Iranian EFL learners with the age range of 11-21, at the pre-intermediate level and from two English language institutes. They were assigned to two experimental groups: a one-way-task group and a two-way-task group. Knowledge of the intended lexes was established by a pre-test. The experimental groups underwent different treatments for eight 30-minute sessions during which they told stories based on the picture-cued stories. After the treatment, a post-test and a delayed post-test were administered. The results of the one-way repeated measures ANOVAs indicated that both one-way and two-way tasks had a significant effect on the learning of lexis. Meanwhile, gain scores of pretest, posttest, and delayed posttest were compared using independent samples T-tests. It indicated that twoway tasks, compared to one-way tasks, were more effective in the retention of lexes. The findings of this study could attract the attention of material developers to include one-way and two-way tasks in the books. Teacher trainers and EFL teachers could utilize similar task types in the classroom and could provide EFL learners with an effective way of vocabulary acquisition.
\end{abstract}

Index Terms - task-based language teaching, one-way task, two-way task, lexical learning

\section{INTRODUCTION}

When learners attend English courses, one of the driving forces of their attendance is the ability to speak in the target language. In attaining the goal, one of the important components of language- vocabulary- is required to be learnt in a way that facilitates the process. Hence, a change was felt in teaching methodology; from synthetic language teaching strategy and as Rutherford (1987) calls it the "accumulated entities" view of language learning to an analytic language teaching strategy in which the focus falls on the communicative purposes for which the language is used. As a result, communicative language teaching (CLT) was established in the early 1970s as a reaction against previous traditional approaches of teaching learners a fixed set of grammatical structures and fragmentary lexical uses. With an emphasis on the main role of learners as well as the practical use of language in situations other than educational setting, CLT and its different aspects came into prominence.

One of the branches of CLT is related to task-based language teaching (TBLT) and task-based syllabi which refers to teaching a second/foreign language that seeks to engage learners in interactionally meaning-based (Breen, 1989) and outcome-driven language use by having them perform a series of tasks comparable to real world activities (Ellis, 2003; Skehan, 1998; Willis \& Willis, 2001). In this approach the prime focus is given to the concept of "task" as a distinguishing feature. Different authors defined task according to specific purposes (Nunan, 1989; Skehan, 1998; Willis, 1996).

One of the design factors regarding the manipulation of tasks has to do with how information is distributed among the participants and how it flows during interaction; whether it is directed in one-way or two-way. According to Mackey and Gass (2005) in one-way tasks, one of the members possesses the information, which she/he must provide the listener with to do something with it. While in two-way tasks, each member has part of the information to share with the others for the task to be completed successfully. Applying one-way and two-way tasks in the interactions may affect the learning process. This study reported in this article is one contribution to this area and focused on the effect of one-way and two-way tasks on learners' lexical learning.

\section{LITERATURE REVIEW}

Two early applications of a task-based approach within a communicative framework for the language teaching were the Malaysian Communicational Syllabus (1975) and the Bangalore Project carried out by Bretta and Davies in 1985 
and Prabhu in 1987. In his Second Language Pedagogy, Prabhu (1987) provided more information and accurate details on the Banglore project.

Over the last three decades, in the SLA field, there have been varying interpretations of what constitutes a 'task' in language education (Breen, 1989; Bygate, Skehan \& Swain, 2001; Crookes, 1986; Ellis, 2003; Lee, 2000; Nunan, 1989; Prabhu, 1987; Skehan, 1996); and it covers a wide variety of topics such as whether the tasks involve real world activities or they are designed for pedagogic purposes, whether they are merely defined in communicative terms or they involve communication, whether they are directed at fostering receptive or productive skills, and whether all tasks necessitate language use and production, i.e., if they have a linguistic or non-linguistic outcome. In order to create a better understanding of the concept of task, some areas need to be elaborated on.

\section{TBLT and Vocabulary Learning}

In TBLT, in order for an effective interaction and outcome to occur, some linguistic features are required. One feature to mention is vocabulary learning. According to Ellis (1999), vocabulary learning in TBLT means the incidental acquisition of vocabulary that occurs when learners do not focus their attention to learn that specific vocabulary. Ellis mentions two reasons to focus on vocabulary acquisition. The first reason is that vocabulary development is now recognized by researchers, as well as by learners, as an important and main aspect of learning a new language. In the last few decades, applied linguists, particularly SLA researchers, have increasingly paid attention to vocabulary learning (Huckin \& Coady, 1999; Hatch \& Brown, 1995; Schmitt \& McCarthy, 1997).

The second reason proposed by Ellis (1999) is that vocabulary acquisition is easier to investigate than the acquisition of grammatical knowledge. Learners need ample exposure to L2 input in order to attain specific grammatical or pragmatic features. In contrast, the incidental acquisition of L2 vocabulary that is gained by quite small amounts of exposure can be measured relatively easily.

Recently, with the development of task-based approaches to teaching different components of language, pedagogical tasks were identified as another principal source of incidental vocabulary learning (Fallahrafie, Rahmany \& Sadeghi, 2015; Hedayatipanah, Mirzaei \& Azizifar, 2015; Newton, 1995; Shintani, 2012; Wesche \& Paribakht, 2000).

In a study carried out by Ziyaeemehr (2013), the effectiveness of task types on vocabulary learning in multilevel language ability classes was investigated. As a result, the treatment groups that received instruction through those task types indicated no statistically significant difference whereas their language proficiency level significantly influenced their performance in vocabulary learning.

Javanbakht (2011) observed the impact of three task types, reading comprehension, reading comprehension with fillin gaps, and sentence writing on incidental vocabulary learning and retention of Iranian male elementary learners. The results indicated the significant impact of task involvement on the incidental learning of vocabulary by male elementary EFL learners.

Khodareza and Shabani (2016) compared the effect of one-way versus two-way tasks on Iranian intermediate EFL learners' phrasal verb learning. The participants were sixty EFL learners majoring in TEFL studying in the second semester of academic year 2015. The outcome revealed that both the OWT group and the TWT group had vocabulary gains but the effect of two-way tasks on phrasal verbs learning was more noticeable than that of the one-way task.

Pourramzan, Taghipour Bazargani, and Zohouri Vaghei (2016) attempted to investigate the effect of one-way versus two-way tasks on the development of collocation competence among Iranian intermediate EFL learners. Data analysis revealed the fact that two-way task group outperformed the one-way task group. The findings also showed that both groups progressed from pretest to posttest.

Most studies have witnessed the positive effect of different task types on learners' vocabulary learning and acquisition. Since the researchers realized a vacuum in dealing more with the effect of one-way and two-way tasks on lexical learning of EFL learners, in this thesis, an attempt has been made to further investigate the issue to provide support for the use of one-way and two-way tasks in syllabus design and curriculum development.

\section{RESEARCH QUESTIONS}

The following research questions presented the aim of the study:

Q1- Do one-way tasks affect Iranian pre-intermediate EFL learners' lexical knowledge and long-term retention of lexis?

Q2- Do two-way tasks affect Iranian pre-intermediate EFL learners' lexical knowledge and long-term retention of lexis?

Q3- Is there any significant difference between the effect of one-way and two-way tasks on Iranian pre-intermediate EFL learners' (long-term) retention of lexis?

\section{MATERIALS AND METHODS}

\section{A. Participants}

Participants in the study were 40 pre-intermediate Iranian EFL learners, with the age range of 11 to 21 , all Persian native speakers, with an almost two-year experience of second language instruction. Meanwhile, learners' consent on participating in the study was obtained before the study. 


\section{B. Design}

This quantitative quasi-experimental study utilized a pretest-posttest comparison group design and a delayed posttest with four Iranian EFL classes in 2 language institutes as the experimental groups. Both experimental groups received a one-month treatment. One group was exposed to one-way tasks (OWT) and the other to two-way tasks (TWT). The posttest was administered one week after the last treatment session during which learners in both groups carried out one task per session. Meanwhile, in order to examine the long-term effect of the study, a delayed posttest was also conducted one month and a week after the treatments.

\section{Instruments}

The instruments applied in the present study were of three types as follows.

1. Oxford Quick Placement Test

In order to find out the groups' homogeneity of English proficiency, an Oxford Quick Placement Test (OQPT) with a total number of 50 multiple choice items was administered in 35 minutes. In order to select the intended participants, those classes were selected that were at the pre-intermediate level with the scores ranging from 10-18.

2. Pretest

The pretest to which the participants were exposed was a four-section, 17-item teacher-constructed test of vocabulary, for the test was designed to assess the vocabulary learning of learners. The test consisted of selected response item types, i.e., 10 multiple-choices, and 7 fill-in-the-blanks. Of 17 items for the vocabulary section, 5 questions were presented as distractors in order to avoid participants' attention to the target features during testing. The time allotted to the vocabulary pretest and posttest was 25 minutes, and all these tests sessions were supervised by the researcher.

\section{Posttest}

This test which was administered one week after the treatment sessions. It was equal in all respects to pretest except for the arrangement of some items. It is worth mentioning that some items of the test in the posttest were rearranged, the primary purpose of which was to reduce or avoid the testing effect and subjectivity.

4. Delayed Posttest

To investigate whether the treatment had any effect on the long term retention of learners' acquisition, another test was administered one month after the posttest. The content of the delayed posttest was the same as the pretest and posttest except for the arrangement of some items.

\section{Treatment}

The materials were 8 picture-cued stories (pictures as a sequence of cues to tell a story), one for each treatment session, which were presented to each group. The stories included three popular English stories by the names of "The Gingerbread Man", "The Little Red Hen", "Red Riding Hood"; one picture-cued story was taken from page 73 of Second Language research: Methodology and Design by Mackey and Gass (2005) and four other picture-cued stories were taken from web sources. For controlling learners' tasks, their voices were recorded during the process of storytelling.

\section{E. Procedure}

The experimental sequence of the study was carried out over a period of one month during winter 2016. First, an OQPT was administered to all participants by the researcher. Then, of four intact classes, those approximately homogeneous and at the pre-intermediate level were assigned to two experimental groups; a one-way-task group (OWT) group and a two-way-task (TWT) group. The OWT group (EG 1) consisted of 19 participants and the TWT group (EG 2) had 21 participants. One week prior to the first treatment session, all participants took a vocabulary pretest. Then, the two groups underwent different treatments. The treatments consisted of eight sessions which were conducted in thirty minutes, two sessions per week for each EG. The last treatment session was followed by a vocabulary posttest a week later. In addition, in order to assess the long-term effect of the treatments, a delayed posttest was also administered after a month.

Prior to the treatment, the vocabulary test as well as two out of eight tasks were pilot-tested on a separate group of learners similar to those in the experiment. After calculating item difficulty and item discrimination, some ineffective items were either excluded or modified from the final version of the test. For measuring the reliability of the test, a testretest $(r=0.79)$ was carried out. Moreover, the test's internal consistency was measured by calculating Cronbach's alpha coefficient. The obtained Cronbach's alpha for the test was 0.94. To investigate learners' performance regarding the implementation of tasks and proper use of targeted lexis, all data were audio-recorded by voice-recorders.

At the beginning of each session, based on the treatment group type, EG1 and EG2, picture-cued stories were distributed among learners. Pictures were cut into separate pieces. For EG1, each learner received all pieces of pictures and had to make the story individually and then describe it to his/her partner. One point the researcher considered in this type of task was that both learners in one group needed to describe the story to one another because in case, one learner only described the story, there would be a possibility that the other partner did not pay enough attention and the aim would not be met. For EG2, learners were divided into groups of two. Each learner had part of information; picture parts were distributed equally between the two learners or when the number of parts was odd, one learner had one part more than his/her partner. Then, they negotiated with each other to make the story together. Each treatment session 
consisted of a pre-task phase and a task phase. The pre-task phase lasted about 10 minutes. The task phase lasted about 20 minutes.

\section{RESULTS}

\section{A. The First Null Hypothesis}

The first null hypothesis of this study addressed that "One-way tasks do not affect Iranian pre-intermediate EFL learners' lexical knowledge and long-term retention of lexis". To investigate this hypothesis, a one-way repeated measures ANOVA was conducted. The results are presented in Table 4.1 to compare vocabulary scores of OWT group on the pretest, posttest and delayed posttest at Time 1 (prior to the treatment), Time 2 (following the treatment) and Time 3 (one month and a week after the treatment). There was a significant effect for time, Wilks' Lambda $=0.146, F(1$, $17)=49.657, p<0.001$, multivariate partial eta squared $=0.854$.

TABLE 1

ONE-WAy REPEATED MEASURES ANOVA OF OWT ON VOCABULARY LEARNING (MulTIVARIATE TESTS ${ }^{A}$ )

\begin{tabular}{llllllll}
\hline \hline Effect & & Value & F & Hypothesis df & Error df & Sig. & Partial Eta Squared \\
\hline Time & Pillai's Trace & .854 & $49.657^{\mathrm{b}}$ & 2.000 & 17.000 & .000 & .854 \\
& Wilks' Lambda & .146 & $49.657^{\mathrm{b}}$ & 2.000 & 17.000 & .000 & .854 \\
& Hotelling's Trace & 5.842 & $49.657^{\mathrm{b}}$ & 2.000 & 17.000 & .000 & .854 \\
& Roy's Largest Root & 5.842 & $49.657^{\mathrm{b}}$ & 2.000 & 17.000 & .000 & .854 \\
\hline \hline
\end{tabular}

a. Design: Intercept

Within Subjects Design: Time

b. Exact statistic

Inferential statistics in Table 1 and 2 indicate that the significant difference between group means is between Time 1 and 2 as well as Time 1 and 3. In other words, OWT had a great short-term and long-term effect on vocabulary knowledge of pre-intermediate EFL learners. Therefore, the null hypothesis is rejected at $p<0.05$. As the results indicate participants' scores in the delayed posttest were lower than their scores in the posttest because they had a one-month interval between the tests and there is a probability of forgetting the parts of the subject of the study in this type of task.

TABLE 2

ONE-WAY REPEATED MEASURES ANOVA OF OWT ON VOCABULARY LEARNING (PAIRWISE COMPARISONS) Measure: MEASURE_1

\begin{tabular}{|c|c|c|c|c|c|c|}
\hline \multirow[b]{2}{*}{ (I) Time } & \multirow[b]{2}{*}{ (J) Time } & \multirow{2}{*}{$\begin{array}{l}\text { Mean Difference } \\
(\mathrm{I}-\mathrm{J})\end{array}$} & \multirow[b]{2}{*}{ Std. Error } & \multirow[b]{2}{*}{ Sig. ${ }^{b}$} & \multicolumn{2}{|c|}{ 95\% Confidence Interval for Difference } \\
\hline & & & & & Lower Bound & Upper Bound \\
\hline \multirow[t]{2}{*}{1} & 2 & $-3.421^{*}$ & .336 & .000 & -4.308 & -2.534 \\
\hline & 3 & $-3.158^{*}$ & .441 & .000 & -4.322 & -1.994 \\
\hline \multirow[t]{2}{*}{2} & 1 & $3.421^{*}$ & .336 & .000 & 2.534 & 4.308 \\
\hline & 3 & .263 & .357 & 1.000 & -.680 & 1.206 \\
\hline \multirow[t]{2}{*}{$\overline{3}$} & 1 & $3.158^{*}$ & .441 & .000 & 1.994 & 4.322 \\
\hline & 2 & -.263 & .357 & 1.000 & -1.206 & 680 \\
\hline
\end{tabular}

Based on estimated marginal means

*. The mean difference is significant at the .05 level.

b. Adjustment for multiple comparisons: Bonferroni.

\section{B. The Second Null Hypothesis}

Considering the second research question, the following null hypothesis is as follows: "Two-way tasks do not affect Iranian pre-intermediate EFL learners' lexical knowledge and long-term retention of lexis". To investigate this hypothesis, a one-way repeated measures ANOVA was conducted. Table 3 compares vocabulary scores of TWT group on the pretest, posttest and delayed posttest at Time 1 (prior to the treatment), Time 2 (following the treatment) and Time 3 (one month and a week after the treatment). There was a significant effect for time, Wilks' Lambda $=0.101, F(1$, 19) $=85.000, p<0.001$, multivariate partial eta squared $=0.899$. 
TABLE 3

ONE-WAY REPEATED MEASURES ANOVA OF TWT ON VOCABULARY LEARNING (MULTIVARIATE TESTS ${ }^{\mathrm{A}}$ )

\begin{tabular}{|c|c|c|c|c|c|c|c|}
\hline Effect & & Value & $\mathrm{F}$ & Hypothesis df & Error df & Sig. & $\begin{array}{l}\text { Partial Eta } \\
\text { Squared }\end{array}$ \\
\hline \multirow[t]{4}{*}{ Time } & Pillai's Trace & .899 & $85.000^{\mathrm{b}}$ & 2.000 & 19.000 & .000 & .899 \\
\hline & Wilks' Lambda & .101 & $85.000^{\mathrm{b}}$ & 2.000 & 19.000 & .000 & .899 \\
\hline & Hotelling's Trace & 8.947 & $85.000^{\mathrm{b}}$ & 2.000 & 19.000 & .000 & .899 \\
\hline & Roy's Largest Root & 8.947 & $85.000^{\mathrm{b}}$ & 2.000 & 19.000 & .000 & .899 \\
\hline
\end{tabular}

a. Design: Intercept

Within Subjects Design: Time

b. Exact statistic

Data from Table 4 reveal that the significant difference between group means is between Time 1 and 2 as well as Time 1 and 3. In other words, TWT had a great short-term and long-term effect on vocabulary knowledge of preintermediate EFL learners. Therefore, the null hypothesis is rejected at $p<0.05$.

TABLE 4

ONE-WAY REPEATED MEASURES ANOVA OF TWT ON VOCABULARY LEARNING( PAIRWISE COMPARISONS) Measure: MEASURE

\begin{tabular}{|c|c|c|c|c|c|c|}
\hline \multirow[b]{2}{*}{ (I) Time } & \multirow[b]{2}{*}{ (J) Time } & \multirow{2}{*}{$\begin{array}{l}\text { Mean Difference } \\
(\mathrm{I}-\mathrm{J})\end{array}$} & \multirow[b]{2}{*}{ Std. Error } & \multirow[b]{2}{*}{ Sig. ${ }^{b}$} & \multicolumn{2}{|c|}{ 95\% Confidence Interval for Difference } \\
\hline & & & & & Lower Bound & Upper Bound \\
\hline \multirow[t]{2}{*}{1} & 2 & $-4.524^{*}$ & .363 & .000 & -5.471 & -3.576 \\
\hline & 3 & $-4.857^{*}$ & .443 & .000 & -6.016 & -3.699 \\
\hline \multirow[t]{2}{*}{2} & 1 & $4.524^{*}$ & .363 & .000 & 3.576 & 5.471 \\
\hline & 3 & -.333 & .386 & 1.000 & -1.343 & .676 \\
\hline \multirow[t]{2}{*}{3} & 1 & $4.857^{*}$ & .443 & .000 & 3.699 & 6.016 \\
\hline & 2 & .333 & .386 & 1.000 & -.676 & 1.343 \\
\hline
\end{tabular}

Based on estimated marginal means

*. The mean difference is significant at the .05 level.

b. Adjustment for multiple comparisons: Bonferroni.

\section{The Third Null Hypothesis}

Considering the third research question, the following null hypothesis is as follows: "There is not any significant difference between the effect of one-way and two-way tasks on Iranian pre-intermediate EFL learners' (long-term) retention of lexis". To investigate this hypothesis, two independent samples T-tests were conducted alternatively. Table 5 and 6 indicate the significance.

TABLE 5

INDEPENDENT SAMPLES T-TEST FOR GAIN SCORES OF THE VOCABULARY PRETEST-POSTTEST BETWEEN OWT AND TWT GROUP

\begin{tabular}{|c|c|c|c|c|c|c|c|c|c|c|}
\hline & & \multicolumn{9}{|c|}{$\begin{array}{l}\text { Levene's Test for } \\
\text { Equality of } \\
\text { Variances } \quad \text { T-test for Equality of Means }\end{array}$} \\
\hline & & \multirow[b]{2}{*}{$\mathrm{F}$} & \multirow[b]{2}{*}{ Sig. } & \multirow[b]{2}{*}{$\mathrm{T}$} & \multirow[b]{2}{*}{$\mathrm{df}$} & \multirow{2}{*}{$\begin{array}{l}\text { Sig. ( } 2- \\
\text { tailed) }\end{array}$} & \multirow{2}{*}{$\begin{array}{l}\text { Mean } \\
\text { Difference }\end{array}$} & \multirow{2}{*}{$\begin{array}{l}\text { Std. Error } \\
\text { Difference }\end{array}$} & \multicolumn{2}{|c|}{$\begin{array}{l}95 \% \text { Confidence } \\
\text { Interval of the } \\
\text { Difference }\end{array}$} \\
\hline & & & & & & & & & Lower & Upper \\
\hline \multirow{2}{*}{$\begin{array}{l}\text { Gainscore- } \\
\text { pretestposttest- } \\
\text { vocab }\end{array}$} & $\begin{array}{l}\text { Equal variances } \\
\text { assumed }\end{array}$ & 1.50 & .23 & -2.22 & 38 & .033 & -1.10 & .498 & -2.110 & -.095 \\
\hline & $\begin{array}{l}\text { Equal variances } \\
\text { not assumed }\end{array}$ & & & -2.23 & 37.98 & .032 & -1.11 & .494 & -2.104 & -.102 \\
\hline
\end{tabular}

TABLE 6

INDEPENDENT SAMPLES T-TEST FOR GAIN SCORES OF THE VOCABULARY PRETEST-DELAYED POSTTEST BETWEEN OWT AND TWT GROUP

\begin{tabular}{|c|c|c|c|c|c|c|c|c|}
\hline & \multicolumn{8}{|c|}{ 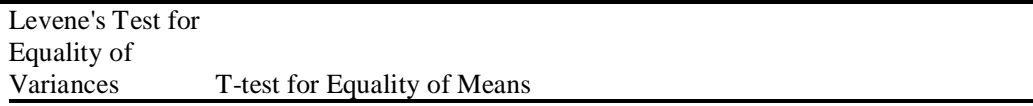 } \\
\hline & \multirow[b]{2}{*}{ F } & \multirow[b]{2}{*}{$\mathrm{T}$} & \multirow[b]{2}{*}{ Df } & \multirow{2}{*}{$\begin{array}{l}\text { Sig. }(2- \\
\text { tailed) }\end{array}$} & \multirow{2}{*}{$\begin{array}{l}\text { Mean } \\
\text { Difference }\end{array}$} & \multirow{2}{*}{$\begin{array}{l}\text { Std. Error } \\
\text { Difference }\end{array}$} & \multicolumn{2}{|c|}{$\begin{array}{l}95 \% \text { Confidence } \\
\text { Interval of the } \\
\text { Difference }\end{array}$} \\
\hline & & & & & & & Lower & Upper \\
\hline \multirow[t]{2}{*}{$\begin{array}{l}\text { Gainscorepretestdelayedpostte } \\
\text { stvocab }\end{array}$} & .56 & -2.71 & 38 & .010 & -1.70 & .627 & -2.969 & -.430 \\
\hline & & -2.72 & 37.92 & .010 & -1.70 & .625 & -2.965 & -.433 \\
\hline
\end{tabular}


The data in Tables 5 and 6 reveal that TWT had a more significant effect on participants' lexical acquisition both in short-term $(p=0.03)$ and long- term intervals $(p=0.01)$. Therefore, the null hypothesis is rejected at $p<0.05$, which means that there is a significant difference between the gain scores of TWT group compared to OWT group in short-term and long-term regarding lexical learning.

\section{Discussion}

The main objective in this study was to revisit the issue of the importance of one type of task with its two levels (i.e., one-way and two-way) involved in the process of vocabulary acquisition.

The first and second null hypotheses jointly stated that "one-way and two-way tasks do not affect Iranian preintermediate EFL learners' lexical knowledge and long-term retention of lexis". Data analysis revealed that the experimental groups that received treatment in form of both OWT and TWT improved considerably from pretest to posttest and delayed posttest. Therefore, the first and second null hypotheses are rejected. Based on the present quasiexperimental study, there is a difference in the effect of one-way and two-way tasks on Iranian pre-intermediate EFL learners' lexical knowledge and long-term retention of lexis. These findings support the previous claims for the efficacy of one-way and two-way tasks on learners' lexical learning (Khodareza \& Shabani, 2016). Khodareza and Shabani (2016) compared the effect of one-way versus two-way tasks on Iranian intermediate EFL learners' phrasal verb learning.

Furthermore, the findings lend support to a previous study which has demonstrated the benefits of task-based approach on vocabulary learning and enhancement in ESP courses (Hedayatipanah, Mirzaei \& Azizifar, 2015). Based on their results, they concluded that task-based approach was more effective in teaching technical vocabularies.

There is also one study that, not in line with the present study, has found no significant difference on the effectiveness of task types on vocabulary learning (Ziyaeemehr, 2013). The distinctions between the two studies are, the type of task that was implemented, i.e., one-way tasks, and the post-task phase which was excluded from the present study for the lack of time. However, there is one result that supports the result of the present study. It shows dialogs and interactions are more appropriate tasks to improve students' language ability in terms of vocabulary knowledge.

As the results reveal, one-way and two-way tasks had a significant effect on the acquisition of lexes in both short and long-term intervals. However, the significant difference was higher in the TWT group compared to OWT group. Therefore, the study confirms that both one-way and two-way tasks are appropriate means in the learning of lexis.

The results are in line with Newton' (1995) and Shintani's (2012) study. There are some other studies which investigated the effect of various tasks types on vocabulary learning and acquisition of EFL and ESL learners (Fallahrafie, Rahmany \& Sadeghi, 2015; Javanbakht, 2011). Although these studies and the current study are not exactly comparable, the common aim they share is that they all state the effectuality that implementing tasks has on lexical acquisition of learners.

Regarding the third null hypothesis, data analysis revealed that the experimental groups that received treatment in form of TWT improved considerably from pretest to posttest and delayed posttest than OWT group. Therefore, the third null hypothesis is rejected. Based on the present study, there is a significant difference between the effect of one-way and two-way tasks on Iranian pre-intermediate EFL learners' (long-term) retention of lexis.

The present study is congruent with Pourramzan, Taghipour Bazargani, and Zohouri Vaghei (2016). Their study confirmed that two-way tasks are more beneficial in teaching and learning of collocations than one-way tasks.

The results of the present study are congruent with Long's (1983) Interaction Hypothesis which claims that learners acquire language through interaction with others; the more opportunities available for interaction, the more likely acquisition is to happen. Meanwhile, the findings of most of the above studies were in line with Ellis' (2003) notion that TBLT is a successful approach to second/foreign language teaching which emphasizes the implementation of various tasks to create effective results in L2 learning context.

\section{CONCLUSION}

The current study was conducted to assess the effect of one-way and two-way tasks on vocabulary learning of Iranian intermediate EFL learners. The obtained data was analyzed using SPSS22 software. The analyses showed that both oneway and two-way tasks had a significant effect on vocabulary learning. It was also concluded that two-way tasks were more effective in vocabulary learning than one-way tasks.

This study has several limitations. Among them are a small sample, conducting the study in the dual role of a researcher and a teacher, the participants' English level, sample size, and the limited time which was allotted to the researcher to conduct the study. The present study showed the effectiveness of OWT and TWT on the acquisition of vocabulary in certain circumstances under which the study was conducted. It should be noted that many questions concerning foreign/ second language vocabulary acquisition need to be answered, and the key to answering these questions is the findings of the future empirical research in these problematic areas. 


\section{REFERENCES}

[1] Breen, M. (1989). The evolution cycle for language learning tasks. In R. K. Johnson (Ed). The second language curriculum. Cambridge: Cambridge University Press.

[2] Bygate, M., Skehan, P., \& Swain, M. (Eds.) (2001). Researching pedagogic tasks, second language learning, teaching and testing. Harlow: Longman.

[3] Crookes, G. (1986). Task classification: A cross-disciplinary review. Technical Report, 4. Honolulu: Center for second language classroom research, Social science research institute, University of Hawaii.

[4] Ellis, R. (1999). Factors in the incidental acquisition of second language vocabulary from oral input. In R. Ellis (Ed.). Learning a second language through interaction (pp. 35-61). Amsterdam, Philadelphia: John Benjamins Publishing Company.

[5] Ellis, R. (2003). Task-based language learning and teaching. Oxford: Oxford University Press.

[6] Fallahrafie, Z., Rahmany, R., \& Sadeghi, B. (2015). The effect of task-based teaching on incidental vocabulary learning in English for specific purposes. Cumhuriyet Science Journal, 36(3), 836-846. Retrieved December14, 2015, from http://dergi.cumhuriyet.edu.tr/cumuscij/article/view/5000118653.

[7] Hatch, E. \& Brown, C. (1995). Vocabulary, Semantics, and Language Education. Cambridge: Cambridge University Press.

[8] Hedayatipanah, R., Mirzaei, M., \& Azizifar, A. (2015). The basic impacts of task-based approach upon Iranian EFL learners' vocabulary enhancement in ESP classes. International Journal of Language Learning and Applied Linguistics World, 8(1), 136-145.

[9] Huckin, T., \& Coady, J. (1999). Incidental vocabulary acquisition in a second language. Studies in Second Language Acquisition, 21(2), 181-193.

[10] Javanbakht, Z.O. (2011). The impact of tasks on male Iranian elementary EFL learners' incidental vocabulary learning. Language Education in Asia, 2(1), 28-42.

[11] Khodareza, M. R., \& Shabani, G. H. (2016). Comparing the effect of one-way versus two-way tasks on Iranian intermediate EFL learners' phrasal verb learning. Journal of Studies in Education, 6(1), 129-146. Retrieved July 08, 2016, from http://dx.doi.org/10.5296/jse.v6i1.8799.

[12] Lee, J. (2000). Tasks and communicating in language classrooms. Boston: McGraw-Hill.

[13] Long, M. H. (1983). Native speaker/non-native speaker conversation and the negotiation of comprehensible input. Applied Linguistics, 4, 126-141

[14] Mackey, A., and Gass, S. M. (2005). Second language research: Methodology and design. New Jersey, US: Lawrence Erlbaum Associates, Inc., Publishers.

[15] Newton, J. (1995). Task-based interaction and incidental vocabulary learning: A case study. Second Language Research, 11(2), 159-177.

[16] Nunan, D. (1989). Designing tasks for the communicative classroom. Cambridge: Cambridge University Press.

[17] Pourramzan, P., Taghipour Bazargani, D., \& Zohouri Vaghei, A. (2016). On the impact of one-way vs. two-way tasks on Iranian intermediate EFL learners' collocation competence. Modern Journal of Language Teaching Methods, 6 (5), 181-188.

[18] Prabhu, N. S. (1987). Second language pedagogy. Oxford: Oxford University Press.

[19] Rutherford, W. (1987). Second language grammar: Learning and teaching. London: Longman.

[20] Shintani, N. (2012). Input-based tasks and the acquisition of vocabulary and grammar: A process-product study. Language Teaching Research, 16(2), 253-279.

[21] Skehan, P. (1996). A framework for the implementation of task-based instruction. Applied Linguistics, 17, 38-62.

[22] Skehan, P. (1998). A cognitive approach to language learning. Oxford, UK: Oxford University Press.

[23] Schmitt, N., \& McCarthy M. J. (Eds.) (1997). Vocabulary: Description, Acquisition and Pedagogy. Cambridge: Cambridge University Press.

[24] Wesche, M. B., \& Paribakht, T. S. (2000). Reading-based exercises in second language vocabulary learning: An introspective study. The Modern Language Journal, 84(2), 196 -213.

[25] Willis, J. (1996). A framework for task-based learning. Harlow, England: Longman

[26] Willis, D. \& Willis, J. (2001). Task-based language learning. In R. Carter \& D. Nunan (Eds.), The Cambridge to teaching to speakers of other languages (pp. 173-79). Cambridge: Cambridge University Press.

[27] Ziyaeemehr, A. (2013). Investigating the effectiveness of task types on vocabulary learning in multilevel language ability classes. European Online Journal of Natural and Social Sciences, 2(2), 659-667. [Online] 3119. Retrieved March 18, 2016, from http://european-science.com.

Saeedeh Shadabi is an M.A. student in English language teaching in Islamic Azad University, Yazd Branch, Yazd, Iran. She is interested in doing research on task based language teaching.

Mohammad Golshan holds a PhD in TEFL. He is an assistant professor of TEFL at the Department of English at the Islamic Azad University, Maybod Branch, Yazd, Iran.

Sima Sayadian holds a PhD in TESL. She is an assistant professor of TESL at the Department of English at the Islamic Azad University, Maybod Branch, Yazd, Iran. 